\title{
Recenzja: Zaburzenia płynności mowy - teoria i praktyka, tom 2, pod redakcją Katarzyny Węsierskiej i Mikołaja Witkowskiego, Wydawnictwo Uniwersytetu Śląskiego, Katowice 2020, ss. 286
}

Publikacja Zaburzenia płynności mowy - teoria i praktyka pod redakcją Katarzyny Węsierskiej i Mikołaja Witkowskiego stanowi kontynuację dobrze przyjętej przez czytelników wcześniejszej publikacji pod tym samym tytułem. Na tom drugi, podzielony na trzy części, składa się wiele artykułów poświęconych niepłynności mowy o charakterze jąkania. Z przeglądu wyłania się logiczny, przemyślany zamysł - prezentacja niepłynności mowy z perspektywy wszystkich podmiotów zaangażowanych w terapię.

Część pierwsza - Logopedia oparta na dowodach - doniesienia z badań - to rzetelna wiedza przybliżająca czytelnikowi zagadnienia jąkania z perspektywy historycznej i socjokulturowej. Wart podkreślenia jest fakt, że artykuły tu zamieszczone stanowią prezentację wyników badań własnych, są więc niezwykle cenne metodologicznie i naukowo. Dla osób poszukujących inspirującej perspektywy spojrzenia na jąkanie godny uwagi jest artykuł traktujący o możliwości zmiany postaw wobec tego zaburzenia z wykorzystaniem sztuki teatralnej.

Części druga i trzecia stanowią ukłon w stronę odbiorców mających do czynienia $\mathrm{z}$ jąkaniem na co dzień. Pierwsza $\mathrm{z}$ wymienionych analizuje niepłynność mowy z perspektywy klienta, kolejna podkreśla rolę terapeuty w spotkaniach $\mathrm{z}$ osobami mówiącymi niepłynnie. Zawarte tu teksy odsłaniają problemy, z którymi zmagają

\footnotetext{
* Akademia Ignatianum, Wydział Pedagogiczny, Katedra Dydaktyki i Pedagogiki Szkolnej, ul. Kopernika 26, 31-501 Kraków, e-mail: anna.skoczek@ignatianum.edu.pl.
} 
się osoby jąkające się: funkcjonowanie psychospołeczne, metody i techniki poprawiające płynność wypowiedzi czy - jakże rzadko poruszaną - kwestię bilingwizmu w pracy z dzieckiem. Mowa tu zarówno o jąkających się bilingwalnych osobach, jak i dwujęzycznych terapeutach.

Wobec tak wielu pojawiających się w praktyce logopedycznej ofert terapii kierowanych do osób z niepłynną mową, deklaracji i składanych obietnic w kwestii całkowitego upłynnienia mowy ta - jasno wyrażona i poparta dowodami płynącymi $\mathrm{z}$ badań oraz wieloletnim doświadczeniem w pracy logopedycznej - propozycja terapii integrującej podejście modyfikacji jąkania i mówienia bardziej płynnego wydaje się bardzo obiecującą alternatywą. Celem modyfikacji jąkania nie jest brak jąkania, ale jąkanie się bez walki czy unikania, a ogromną pomocą w osiągnięciu takiej postawy jest wykorzystanie technik mówienia bardziej płynnego.

O wykorzystaniu sztuki w terapii i jej nieocenionej roli w balbutologii traktuje artykuł zachęcający do zróżnicowanej terapii jąkania z wykorzystaniem podejścia integrującego różne metody interwencji logopedycznej. Autorki rzetelnie informują o prowadzonych cały czas badaniach nad efektywnością terapii, wskazując jednocześnie na zasadność stosowania terapii wielodyscyplinarnych oraz podejścia integrującego różne metody interwencji logopedycznej.

Ostatnia, trzecia część książki dedykowana jest terapeutom. To ich systematycznie pogłębiana wiedza, kompetencje, umiejętności oraz doświadczenie w pracy logopedycznej są ważnym predyktorem zmian obserwowanych zarówno w kompetencji komunikacyjnej, jak i postawie jąkających się osób. Z cyklu artykułów wyłania się obraz terapeuty przede wszystkim mocno zmotywowanego do pracy z pacjentem mówiącym niepłynnie. To właśnie motywacja jest kluczem do ciągłego uczenia się, zdobywania wysokich kompetencji do wykonywanego zawodu. W parze z podnoszeniem kwalifikacji idzie u balbutologopedy refleksyjność - wszak holistyczne podejście do jąkającego się pacjenta, jego rodziny i najbliższego otoczenia jest podejściem niezbędnym. Mowa tu też o etyce badacza i terapeuty podejmującego się pracy z osobą z niepłynnością mowy. Rozważania oparte są na wytycznych kodeksu etycznego Amerykańskiego Stowarzyszenia Logopedów i Audiologów (ASHA).

Do ustaleń Międzynarodowej Klasyfikacji Funkcjonowania, Niepełnosprawności i Zdrowia ICF odwołuje się także autorka opracowania poświęconego diagnozie funkcjonalnej dziecka jąkającego się w wieku szkolnym. To ważny dla terapeutów przyczynek do tego, jak wieloaspektowo traktować niepłynność mowy, zaczynając takie podejście już od etapu pierwszych diagnostycznych spotkań z dzieckiem.

Godny polecenia jest artykuł traktujący o wzmacnianiu poczucia sprawstwa i samoakceptacji w terapii modyfikacji utrwalonego jąkania. Jego przesłaniem może być zamieszczony przez autorkę cytat: „Akceptacja w terapii nie oznacza nigdy niezmieniania tych sytuacji, które dają się zmienić" [Hayes, Strosahl, Wilson, 2013, s. 354]. Oznacza ona tolerancję niedoskonałości, a także docenienie wartości wysiłku - nawet w sytuacjach, gdy jego efekty nie zawsze są zgodne z naszymi oczekiwaniami. 
Jednym ze sposobów uzyskania poczucia sprawstwa i samoakceptacji jest coaching, opisywany w artykule zamykającym tom. Cennym wkładem w szeroko pojmowany proces terapeutyczny jest budowanie relacji terapeutycznej przez balbutologopedę - traktują o tym dywagacje zamieszczone w jednej z prac. Cieszy fakt dostrzeżenia problemu wpisującego się w zagadnienia powstającej dopiero w Polsce psychologopedii.

Zaprezentowana publikacja stanowi logopedyczny namysł nad diagnostyczno-terapeutycznymi zagadnieniami związanymi z balbutologopedią. Jest skierowana do szerokiego kręgu odbiorców - zarówno bezpośrednio zaangażowanych, jak i tylko (i aż) zainteresowanych niepłynnością mówienia. Lektura książki stanowi wyjątkową okazję do usystematyzowania i poszerzenia wiedzy na temat zagadnień związanych z jąkaniem. Jestem głęboko przekonana, że zaprezentowane treści - mądrze usystematyzowane i precyzyjnie dobrane - staną się inspiracją dla szerokiego kręgu odbiorców; zarówno tych parających się zagadnieniem jąkania naukowo, jak i praktyków balbutologopedów oraz osób doświadczających niepłynności mowy. Wierzę, że założony, główny cel publikacji - niesienie pomocy, wspieranie i wzbogacanie warsztatu terapeutycznego - został przez autorów osiągnięty.

Na zakończenie pragnę podkreślić jeszcze jeden wyjątkowy aspekt książki. Otóż szczególny wydźwięk, nie tylko w odniesieniu do publikacji, ale i ogólnie do współcześnie prowadzonej terapii jąkających się osób, ma wywiad-rozmowa zamieszczony w pierwszym rozdziale tomu. Uczestnicy, „podwójni terapeuci”, a więc osoby doświadczające niepłynności mówienia, a jednocześnie zajmujące się wsparciem profesjonalnym lub pozainstytucjonalnym, wskazują na sukces $\mathrm{w}$ terapii jąkania. Zgodnie twierdzą, że przezwyciężenie jąkania to coś więcej niż tylko uzyskanie płynności mówienia. Osoba z niepłynnością może mówić o sukcesie w terapii we własnym odbiorze jąkania, jeśli - nie zważając na utrudnienia - potrafi swobodnie się komunikować z otoczeniem, nie odczuwa lęku przed kontaktami interpersonalnymi, jeśli wreszcie sens tego, co ma do przekazania, zwycięża nad sposobem wyrażania myśli.

Wsłuchując się w głos ekspertów, dążmy do tego, by jąkający się otwarcie mówili o swoim jąkaniu, mimo niepłynności uzyskiwali życiowe cele, nie traktowali jąkania jak życiowego przekleństwa. To trudne zadanie i dla terapeutów, i dla samych jąkających się, i wreszcie dla społeczeństwa, ale możliwe do wykonania. Wymaga jednak zmian: w myśleniu i podejściu do terapii logopedów, akceptacji jąkania u doświadczających niepłynności i przebywających z nimi ludzi. Wypowiedź jednej z podwójnych terapeutek - „nauczyłam się wplatać jąkanie w tkankę mojego życia, uznawać za swoją część i odnalazłam dla niego adekwatne miejsce w obrazie samej siebie" [Węsierska, Witkowski, 2020, s. 17] - niech stanie się przesłaniem dla terapeutów i wskazówką dla wszystkich, którym towarzyszy w życiu niepłynność mówienia. 
Literatura

Hayes S.C., Strosahl K.D., Wilson K.G., 2013, Terapia akceptacji i zaangażowania. Proces i praktyka uważnej zmiany, Kraków: Wydawnictwo Uniwersytetu Jagiellońskiego.

Węsierska K., Witkowski M. (red.), 2020, Zaburzenia płynności mowy - teoria i praktyka, t. 2, Katowice: Wydawnictwo Uniwersytetu Śląskiego. 